\title{
FLORIDA STATE UNIVERSITY RADIOCARBON DATES II
}

\author{
G. A. KNAUER, J. R. MARTIN, H. G. GOODELL, and D. S. PHELPS
}

Radiocarbon Dating Laboratory, Department of Geology The Florida State University, Tallahassee, Florida

This list is a compilation of samples dated since September, 1965. It includes a continuation of several series begun in FSU I as well as new series undertaken since that time.

Laboratory operations are essentially the same as those reported in FSU I except for the following minor improvements. Acetylene purification is now accomplished by expanding the gas into a $150-\mathrm{mm}$ polyethylene drying tube, in which the gas passes over equal proportions of Ascarite and phosphorus pentoxide, respectively. The tube is cleaned and refilled after each sample (Noakes, pers. commun.). The main advantages are elimination of the time-consuming process of cleaning the glass beads and removal of the possibility of contamination from samples previously run.

Conversion time for $\mathrm{CO}_{2} \rightarrow \mathrm{C}_{2} \mathrm{H}_{2}$ has been shortened considerably by reducing the amount of lithium metal from the previously recommended $200 \%$ over stoichiometric to approximately $10 \%$ excess (Polach and Stipp, 1966).

\section{SAMPLE DESCRIPTIONS}

I. GEOLOGIC SAMPLES

A. Southeast U.S.

\section{Apalachicola Bay series, Florida}

Wood, shells and peat encountered in drill holes in and around Apalachicola Bay, Florida during investigations of sedimentary and geomorphic Pleistocene evolution of that part of Florida coast by Dr. Jon Schnable.

\section{FSU-35. St. Vincent-1 (24 ft below MSL) \\ FSU-98. St. Vincent-2 \\ (66 to $69 \mathrm{ft}$ below MSL) \\ $12,200 \pm 460$
10,270 B.C. \\ $25,905+830$ \\ 23,955 в.c.}

Wood fragments, probably driftwood, from boring site in beach at Indian Pass ferry landing, St. Vincent Island, Florida $\left(20^{\circ} 40^{\prime} 51^{\prime \prime} \mathrm{N}\right.$ Lat, $85^{\circ} 13^{\prime} 0^{\prime \prime}$ W Long).
FSU-96. St. Vincent-3 ( 33 ft below MSL)
FSU-97. St. Vincent-4 ( 36 to $38 \mathrm{ft}$ below MSL)

$\mathbf{2 4 , 1 4 0} \pm \mathbf{5 0 0}$ 22,190 в.C.

$31,010+1470$
-1800 
FSU-99. St. Vincent-5 ( 70 to $73 \mathrm{ft}$ below MSL)

Wood fragments, probably driftwood, from boring site $2 \mathrm{mi} \mathrm{E}$ of ferry landing, N shore St. Vincent island, Florida $\left(29^{\circ} 41^{\prime} 0^{\prime \prime} \mathrm{N}\right.$ Lat, $85^{\circ}$ $10^{\prime} 51^{\prime \prime}$ W Long).

FSU-92. 11 Mile Oyster Camp-1 (20.5 ft below MSL) $>\mathbf{2 9 , 8 4 0}$

FSU-93. 11 Mile Oyster Camp-2 ( 25 ft below MSL)

$31,015+2975$ 29,065 B.c.

FSU-95. 11 Mile Oyster Camp-3 (30 ft below MSL)

$\begin{aligned} & 23,960+2095 \\ &-2740\end{aligned}$ 22,010 B.C.

Wood fragments, probably driftwood. Boring site located on tidal creek near 11-mi oyster camp opposite St. Vincent Island, Florida $\left(29^{\circ}\right.$ $42^{\prime} 30^{\prime \prime} \mathrm{N}$ Lat, $85^{\circ} 9^{\prime} 18^{\prime \prime} \mathrm{W}$ Long).

\section{FSU-120. East Point-1 (14 ft below MSL)}

$24,185 \pm 560$ 22,235 B.C.

FSU-121. East Point $2-(16.5 \mathrm{ft}$ below MSL $)$ $28,435 \pm 1620$

FSU-122. East Point-3 ( 19 ft below MSL) $32,300 \pm 2570$

FSU-123. East Point-4 (17.5 ft below MSL) 30,350 в.c.

$25,730 \pm 470$ 23,780 в.c.

FSU-124. East Point-5 (21.5 ft below MSL) 32,930 B.c.

$$
34,870+1690
$$

$30,860 \pm 900$

FSU-124. East Point-6 (22.5 ft below MSL) 28,910 в.c.

Wood fragments, probably driftwood. Boring site on mainland shoreline $2.3 \mathrm{mi} \mathrm{E}$ of East Point, Florida $\left(29^{\circ} 45^{\prime} 6^{\prime \prime} \mathrm{N}\right.$ Lat, $84^{\circ} 50^{\prime} 42^{\prime \prime} \mathrm{W}$ Long).

FSU-126. Carrabelle-1 ( $10 \mathrm{ft}$ below MSL) $>25,115$

\section{FSU-127. Carrabelle-2 ( $11 \mathrm{ft}$ below MSL) 19,080 в.c.}

Wood fragments, probably driftwood, from boring site on tidal creek bank on mainland shoreline $4 \mathrm{mi}$ SW of Carrabelle, Florida $\left(29^{\circ}\right.$ $47^{\prime} 54^{\prime \prime} \mathrm{N}$ Lat, $84^{\circ} 44^{\prime} 33^{\prime \prime}$ W Long).

FSU-128. St. George-9

$3280 \pm 70$ 1330 B.c.

Wood fragments, probably driftwood, $17 \mathrm{ft}$ below MSL on beach at

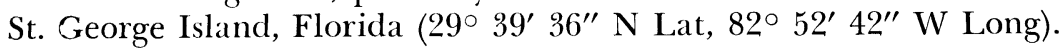


FSU-129. St. George-10

Organic silt at $28 \mathrm{ft}$ below MSL. Boring site one mi SW of boat basin on N shore of St. George Island, Florida (29० $39^{\prime} 42^{\prime \prime} \mathrm{N}$ Lat, $82^{\circ}$ $52^{\prime} 42^{\prime \prime}$ W Long).

FSU-142. St. George-11

Wood fragments, probably driftwood, $47 \mathrm{ft}$ below MSL. Boring site in old dune area on St. George Island, Florida (29० $39^{\prime} 42^{\prime \prime} \mathrm{N}$ Lat, $84^{\circ}$ $51^{\prime} 12^{\prime \prime}$ W Long).

\section{FSU-130. Gorrie Bridge}

$9950 \pm 180$

Shell (Rangia cuneata) at $79 \mathrm{ft}$ below MSL from boring on W end of John Gorrie Memorial Bridge, Apalachicola, Florida $\left(29^{\circ} 43^{\prime} 42^{\prime \prime} \mathrm{N}\right.$ Lat, $84^{\circ} 57^{\prime} 24^{\prime \prime}$ W Long).

General Comment: when plotted on curves of sealevel by Curray (1965) and Shepard (1960) from other stable coasts, dates show present Apalachicola coastal configuration began during Mid-Wisconsin transgression of sea following earlier Sangamon transgression (Schnable, 1966).

\section{B. Atlantic Ocean}

\section{English Channel series}

Barnacle shells dredged from continental slope at depths of 480 to 700 fathoms at western approaches to English Channel $\left(48^{\circ} 32^{\prime} 30^{\prime \prime} \mathrm{N}\right.$ Lat, $10^{\circ} 9^{\prime} 0^{\prime \prime} \mathrm{W}$ Long). Speciments dated in order to help evaluate $\mathrm{C}^{14}$ levels in fossil barnacles of same species from Antarctic.

\section{FSU-117. English Channel-1 (Pachylasma sp.) 3630 в.c. \\ FSU-118. English Channel-2 (Hexalasma hirsutum)

\section{ARCHAEOLOGIC SAMPLES}

\section{White's mound series, Georgia}

The following 10 samples serve to date various occupational features and components at White's mound site (9Ri4), Richmond County, Georgia ( $33^{\circ} 30^{\prime} 0^{\prime \prime} \mathrm{N}$ Lat, $82^{\circ} 10^{\prime} 4^{\prime \prime} \mathrm{W}$ Long). Coll. during $1965 \mathrm{~F}$. S. U. summer excavations under NSF grant GS-675; subm. by D. S. Phelps. Although preliminary site report has been published (Phelps and Burgess, 1964) final analysis of this complex site is incomplete.

FSU-102. White's mound-1

$1540 \pm 270$

Charred wood in association with partially burned half of human cranium in Feature 33, Sq. OL240. 
FSU-104. White's mound-2

$830 \pm 140$

Charred wood from interior of Pit 2, Sq. OL230.

A.D. 1120

FSU-105. White's mound-3

$1670 \pm 110$

Charred wood from interior of Pit 3, Sq. OL230. A.D. 280

FSU-106. White's mound-4

$1380 \pm 150$

Charred wood from area around half of human cranium in Feature 37, Sq. OL240.

FSU-108. White's mound-5

Charred wood in direct association with half of human cranium in Feature 37, Sq. OL240.

FSU-109. White's mound-6

Charred wood from interior fill of historic pit intrusive from Zone 1 . Historic occupation of site reported locally to have begun in early 19th century.

FSU-110. White's mound-7

$1280 \pm 70$

Charred wood from fill of Pit 4, Sq. OL230. A.D. 670

FSU-114. White's mound-8

$920 \pm 290$

Charred wood from beneath cranium of Burial 6, Sq. OL230. Apparently deposited at time of interment.

FSU-116. White's mound-9

$1390 \pm 90$

Charred wood apparently burned in place in fill of Burial 9, Sq. 175L195. Seven small triangular projectile points placed as burial deposit.

FSU-134. White's mound-10

\section{A.D. 1150}

$\mathbf{8 0 0} \pm \mathbf{2 4 0}$

Charred wood from fill of Burial 11, Sq. 17OL240.

FSU-146. Williams site, Florida

$\mathbf{5 4 6 0} \pm \mathbf{5 1 0}$

3510 B.C.

Charred wood from fire pit area in lower levels of shell midden on Site 8Ta32, Taylor County, Florida $\left(30^{\circ} 6^{\prime} 10^{\prime \prime} \mathrm{N}\right.$ Lat, $84^{\circ} 3^{\prime} 50^{\prime \prime} \mathrm{W}$ Long). Sample provenance is Level 6, Sq. OR65, top level of preceramic occupation. Gary and other stemmed projectile points, a triangular blade, deer remains, and oyster shell constitute the associated materials. Coll. and subm. by D. S. Phelps. Comment: provides date for late Archaic stage on West Florida Gulf coast. 
FSU-153. Hiwassee River site, North Carolina

Charred wood from collapsed roof beams of burned house structure at Site Cel5, Cherokee County, North Carolina $\left(35^{\circ} 2^{\prime} 40^{\prime \prime} \mathrm{N}\right.$ Lat, $83^{\circ}$ $57^{\prime} 20^{\prime \prime} \mathrm{W}$ Long). Remains from house are late Cherokee mixed with historic trade materials. Coll. and subm. by B. C. Keel. Comment: estimated occupation of house, A.D. 1776, falls within range of date.

\section{FSU-154. Town Creek mound, North Carolina}

$600 \pm 140$

\section{A.D. 1350}

Charred wood from wall post of final temple structure on Town Creek mound (Mg2), Montgomery County, North Carolina (35 40 $30^{\prime \prime}$ $\mathrm{N}$ Lat, $79^{\circ} 59^{\prime} 0^{\prime \prime} \mathrm{W}$ Long). Sample was encased in paraffin; portion submitted for dating was removed from interior of post not in contact with paraffin. Coll. 1940 by J. L. Coe and subm. 1966. Comment: estimated date of A.D. 1500 for final mound stage and accompanying temple agrees approx. with the l sigma range of date.

Date lists:

REFERENCFS

FSU-I Stipp et al., 1966

Curray, J. R., 1965, Late Quarternary history, continental shelves of the United States, p. 723-735 in Wright, H. E., Jr., and Frey, D. G., editors, The Quarternary of the United States: Princeton, Princeton Univ. Press, 922 p.

Noakes, J. E., Kim, S. M., and Stipp, J. J., 1965, Chemical and counting advances in liquid scintillation age dating: Internat. $\mathrm{C}^{14}$ and $\mathrm{H}^{3}$ Dating Conf., Pullman, Washington, June 7-11, Proc.

Phelps, D. S., and Burgess, R., 1964, A possible case of cannibalism in the early woodland period of Eastern Georgia: Am. Antiquity, v. 30, p. 199-202.

Polach, H. A., and Stipp, J. J., 1966, Single train chemistry for gas proportional and liquid scintillation radiocarbon dating with improved synthesis techniques: Internatl. Jour. Applied Radiation and Isotopes, in press.

Schnable, J. E., 1966, The evolution and development of part of the Northwest Florida coast: Unpub. Ph. D. dissertation, Florida State Univ.

Shepard, F. P., 1960, Rise of sea level along the Northwest Gulf of Mexico, p. 338-344 in Shepard, F. P., and others, editors, Recent sediments, Northwest Gulf of Mexico: Am. Assoc. Petroleum Geologists, $394 \mathrm{p}$.

Stipp, J. J., Knauer, G. A., and Goodell, H. G., 1966, Florida State University radiocarbon dates I: Radiocarbon, v. 8, p. 46-53.

Tamers, M. A., 1965, Routine carbon-14 dating liquid scintillation techniques: In ternat. $\mathrm{C}^{14}$ and $\mathrm{H}^{3}$ Dating Conf., Pullman, Washington, June 7-11, Proc. 